\title{
Pengaruh Pengunjung Terhadap Tingkah Laku dan Konsumsi Makan Rusa Totol (Axis-axis) Pada Penangkaran Rusa Totol di Fakultas Peternakan Unhas
}

\author{
Agil Suharto $^{1}$, Anie Asriany ${ }^{2}$, Ismartoyo ${ }^{3}$
}

\begin{abstract}
ABSTRAK
Rusa totol ( axis - axis ) merupakan salah satu spesies yang tinggal di daerah tropis yang disebut Indian Deerpopulasinya sebanyak di temukan di luar habitat aslinya, khusus di penangkaran, Rusa dapat menjadi daya tarik pengunjung di penangkaran, karena penampilannya yang menarik. Penelitian ini dilakukan pada bulan Juni sampai juli 2019. Di penangkaran rusa Fakultas Peternakan Unhas. Tujuan penelitian ini untuk mengetahui pengaruh pengunjung terhadap pemberian pakan oleh pengunjung terhadap konsumsi makan dan tingkah laku rusa. Metode pengumpulan data melalui pengamatan langsung di lapangan ( observasi survey) dengan metode Time Sampling dilakukan terhadap rusa yang berada di penangkaran, wawancara dengan pengunjung serta studi pustaka. Hasil penelitian menunjukkan bahwa jenis pakan yang diberikan oleh pengunjung meliputi kangkung, wortel, sawi. rumput lapangan, hal ini tidak berpengaruh terhadap tingkah laku dan konsumsi makan rusa, akan tetapi memberikan perubahan pada tingkah laku dan konsumsi makan yang meningkat.
\end{abstract}

Kata Kunci: Pengunjung, Komsumsi rusa, rusa totol (Axis-axis), tingkah laku

\section{PENDAHULUAN}

\section{Latar Belakang}

Rusa totol (Axis axis) merupakan salah satu spesies rusa yang tinggal di daerah tropis yang disebut indian deer, spotted deer atau chital deer.Rusa totol (Axis axis) pada saat ini termasuk satwa yang dilindungi dalam habitat yang baik, mudah berkembangbiak, sehingga satwa ini sangat potensial untuk dikembangkan, bahkan dapat dibudidayakan dengan memberikan nilai ekonomis. Sebagai sumber daya alam rusa mempunyai banyak manfaat terutama sebagai sumber pangan dan objek wisata, disamping sebagai ilmu pengetahuan, pendidikan serta estetika.Hal ini cukup menguntungkan bagi Indonesia yang memiliki potensi rusa cukup besar.

Ciri Rusatotol (Axis axis) mempunyai lingkar dada 75-79 cm, memiliki panjang ekor 20-30 cm, tinggi bahu 110-40 cm, dan berat hidup dewasa 75-100 Kg (Fajri, 2000). Menurut Harianto dan Dewi (2012) berat badan jantan mencapai 70-90 kg dengan tinggi mencapai $90 \mathrm{~cm}$, berat betina mencapai $40-50 \mathrm{~kg}$, dengan tinggi $80 \mathrm{~cm}$ dan berat lahir 3,5 $\mathrm{kg}$, rusa totol (Axis axis)memiliki kulit yang berwarna coklat kemerah-merahan, dipenuhi dengan bintik-bintik besar berwarna putih. Garis gelap membujur sepanjang punggung rusa totol(Axis axis) bagian perut dan kaki berwarna putih.Leher terdapat bagian yang berwarna putih, moncongnya berwarna lebih gelap bila dibandingkan dengan bagian wajah.Ekornya berukuran lebih besar bila dibandingkan dengan jenis rusa pada umumnya dan rusa jantan memiliki alat pertahanan berupa tanduk (ranggah).

Manfaat yang dimiliki rusa menyebabkan perburuan tidak terkendali, sehingga populasi rusa di alam mengalami penurunan.Selain itu, rusaknya habitat di alam baik akibat kegiatan perburuan maupun rusak secara alami, menjadi faktor penting yang mengancam keberlangsungan hidup rusa,untuk menjaga populasi di alam tetap terjaga maka dilakukan 
upaya penangkaran.(Semiadi dan Nugroho, 2004). Usaha penangkaran rusa saat ini telah banyak dilakukan, baik secara in-situ(pemeliharaan atau penangkaran satwa di habitat alam atau di habitat aslinya) maupun $e x$-situ ( pemeliharaan atau penangkaran satwa di luar habitat aslinya)untuk mencapai keberhasilan dalam perkembangbiakannya perlu dipelajari berbagai aspek fisiologi dan ekologinya salah satunya adalah pengetahuan tingkah laku satwa, dan jenis pakan yang diberikan.

Habitat adalah sebuah kawasan yang terdiri dari komponen fisik maupun abiotik yang merupakan satu kesatuan dan dipergunakan sebagai tempat hidup serta berkembangbiaknya satwa liar. Satwa liar menempati habitat yang sesuai dengan lingkungan yang diperlukan untuk mendukung kehidupannya, karena habitat mempunyai fungsi menyediakan makanan, air dan pelindung. Tipe habitat yang diperlukan suatu satwa diidentifikasi melalui pengamatan fungsi-fungsinya, misalnya untuk makan atau bertelur, struktur vegetasi berfungsi sebagai pengaturan ruang hidup suatu individu dengan unsur utama adalah: bentuk pertumbuhan, stratifikasi dan penutupan tajuk (Alikodra, 1990).

Habitat alami rusa terdiri atas beberapa tipe vegetasi seperti savana yang dimanfaatkan sebagai sumber pakan dan vegetasi hutan yang tidak terlalu rapat untuk tempat bernaung (istirahat), kawin, dan menghindarkan diri dari predator (Garsetiasih dan Takandjandji.,2006). Habitat penangkaran berbeda dengan habitat alami, berdasarkan ciri habitatnya, pada habitat penangkaran terdapat peningkatan nutrisi, bertambahnya persaingan intraspesifik untuk memperoleh pakan, berkurangnya pemangsaan oleh predator alami, berkurangnya penyakit dan parasit serta meningkatnya kontak dengan manusia (Dewi dan Wulandari.,2011).

Awal pemeliharaan rusa totol (Axis axis) di Universitas Hasanuddin didatangkan dari Bogor pada tahun 2011 dengan jumlah populasi sebanyak 40 ekor, dengan sistem pemeliharan ekstensif dengan pakan yang diberikan berupa wortel dan kangkung, perpindahan rusa dari tempat penangkaran sebelumnya yaitu di taman pintu satu Univesitas Hasanuddin ke Fakultas Peternakan pada tahun 2017 dengan jumlah populasi 32 ekor, yang berada di penangkaran rusa totol (axis axis) Fakultas Peternakan Universitas Hasanuddin, dengan pola pemeliharaan ekstensif serta pakan yang di berikan berupa wortel dan kangkung.

Sebagai satwa ruminansia, rusa totol (Axis axis) lebih dominan mengkonsumsi rumput-rumputan.Meski rusa totol (Axis axis) lebih dominan mengkonsumsi rumputrumputan, rusa totol (Axis axis) hampir menyukai segala jenis pakan tambahan, seperti bijibijian, pelet, jagung, kentang dan buah-buahan, serta sayur-sayuran, bahkan limbah pertanian (Semiadi dan Nugroho., 2004). Lebih lanjut dijelaskan nutrisi pada pakan yang diberikan sebaiknya terdiri dari air, protein, lemak, energi, mineral dan vitamin yang cukup, karena pada titik tertentu penggabungan protein, lemak dan energi akan menjadi sumber energi bagi rusa tersebut. Misalnya dedak padi mengandung lemak dan energi yang lebih banyak yaitu sekitar 5\% dan $68 \%$ dibanding rumput-rumputan yang hanya sekitar $3 \%$ dan 53\% dan jenis pakan kacang-kacangan misalnya turi, lamtoro mengandung protein yang lebih tinggi yaitu 22\% dibanding rumput-rumputan yang hanya sekitar 10-13\%.

Secara umum, jenis hijauan pilihan yang digunakan sebagai pakan rusa memiliki kandungan gizi yang tinggi dibandingkan dengan rumputlapang yang sehari-hari diberikan di penangkaran.Rusamembutuhkan protein, kalsium, dan fosfor masing-masing adalah 13$16 \%$, $0.45 \%$, dan $0.35 \%$ dari bahan kering pakannya untuk pertumbuhan optimal (Garsetiasih, 1990). Kebutuhan protein rusa totol (Axix axis) yang berumur lebih dari 12 bulan adalah19\% dari bahan kering sedangkan kebutuhan energi rusa adalah $3381 \mathrm{Kkal} / \mathrm{ekor} / \mathrm{hari}$. Oleh sebab itu, pemberian pakan perlu dibuat formulasi(pencampuran bahan pakan lainnya), sehingga kebutuhan pertumbuhan rusa dapat terpenuhi dan tidak terjadi defisiensi zat gizi pakan (Setio, dkk., 2011). Penggunaan energi seekor rusa betina 
untuk keperluan metabolisme, berdiri, berlari, berjalan (1,63 km per hari), mencari makan, bermain dan memamah biak rata-rata $1.908 \mathrm{kcal}$, sedangkan seekor rusa jantan untuk berbagai aktivitas membutuhkan energi $1.907 \mathrm{kcal}$. Energi yang terkandung dalam hijauan (bahan kering) yang dikonsumsi rusa per ekor per hari yaitu 863 gram daun (per gram daun $=3,542 \mathrm{kcal}$ ) dan 107 gram (per gram rumput $=3,174 \mathrm{kcal}$ ) rumput, maka jumlah energi yang tersedia adalah $3.381 \mathrm{kcal}$ (Mukhtar, 1996).

Penelitian ini bertujuan untuk mengidentifikasi pakan rusa yang diberikan oleh pengunjung dipenangkaran serta mengidentifikasi ada tidaknya perubahan konsumsi makan dan tingkah laku rusa totol di penangkaran akibat pemberian pakan oleh pengunjung.

\section{METODE PENELITIAN}

\section{Waktu dan Tempat Penelitian}

Penelitian akan dilaksanakan pada bulan Juni - Juli 2019 di penangkaran Rusa Totol (Axis-axis)Universitas Hasanuddin.

Alat dan Bahan Penelitian

Alat-alat yang digunakan dalam penelitian ini adalah, kamera, timbangan,danalat tulis.Bahan-bahan yang digunakan dalam penelitian ini adalah: wortel, kangkung, konsentrat dan rumput gajah. Sedangkan satwa yang diamati dalam penelitian ini adalah:Rusatotol (Axis axis). Rusa yang dijadikan satwa percobaan sebanyak 30 ekor merupakan rusa totol (Axis axis)jantan dewasa, betina dewasa, jantan muda, betina muda dan anakan (pedet).Di penangkaran rusa totol (Axis axis) Universitas Hasanuddin.

\section{Metode penelitian}

\section{a. Metode pengumpulan data}

Penelitian ini menggunakan metode Observasi/Survei, pengamatan tingkah laku harian dilakukan dengan tekhnik kombinasi antara Scan Sampling Method dan Time Sampling Method (Martin dan Bateson.,1986).Yaitu pengamatan tingkah laku berjalan, mencari makan, istirahat, berdiri.Pencatatanmengikuti pergerakan rusa totol dengan memperhatikan jenis dan frekuensi kegiatan.Setiap individu diamati secara bergantian.Setelah satu individu diamati maka pengamatan dilakukan terhadap individu yang lain (Altman, 1974).

Tabel 1. Perubah Yang Diukur Dalam Penelitian

\begin{tabular}{llll}
\hline Tujuan & Peubah & Data & Metode \\
\hline Tingkah Laku & Makan & Aktivitas & Observasi \\
& Istirahat & Waktu Aktivitas & \\
& Sosial & Distribusi & \\
Konsumsi & Jenis & Jenis Pakan & Observasi \\
& Frekwensi & Waktu Pemberian Pakan & Wawancara \\
& Jumlah & Jumlah Pemberian Pakan & \\
\hline
\end{tabular}

Fokus Pengamatan dilakukan pada satu kelompok rusa totol (axis axis)yang terdiri dari jantan dewasa, betina dewasa, jantan muda, betina muda dan anakan. Waktu pengamatan dilakukan setiap 2 jam dari pengamatan selama 12 jam pada pagi hari (pukul 07.00 - hingga pukul $18.00 \mathrm{Wita}$ ), dan total pengamatan selama 4 minggu. 
Wawancara dilakukan pada pengunjung untuk mengetahui pakan yang diberikan meliputi jenis pakan dan jumlah pakan.. Pengunjung banyak yang datang terjadi pada hari libur, dengan jumlah pengunjung 10 - 40 orang, sedangkan pengunjung pada hari kerja, dengan jumlah $5-15$ orang.

\section{Analisis Data}

Data dan informasi hasil pengamatan rusa di penangkarang di analisis secara deskriptif.

\section{HASIL DAN PEMBAHASAN}

\section{Gambaran Umum Penangkaran Rusa Totol (Axis-axis) Fakultas Peternakan}

Penangkarang rusa fakultas peternakan merupakan lokasi dilakukannya pemeliharaan dan pengembangan jenis rusa totol (Axis-axis). Penangkarang rusa totol yang berada di Fakultas Peternakan, Universitas Hasanuddin memiliki luas kandang $2024,88 \mathrm{~m}^{2}$, yang memiliki lokasi strategis berhadapan sekolah pasca sarjana universitas hasanuddin dan jalan utama kampus, sehingga mudahnya akses ke penangkarang rusa.

Populasi Rusa totol pada penangkaran rusa sebanyak 30 ekor yang terdiri dari Rusa jantan, betina dan anakan. Struktur populasi rusa totol (Axix-Axis) pada Tabel berikut.

Tabel 2. Struktur Populasi Rusa Totol Di Penangkaran.

\begin{tabular}{ccc}
\hline Jenis rusa & $\begin{array}{c}\text { Jumlah rusa kandang I } \\
\text { (Ekor) }\end{array}$ & $\begin{array}{c}\text { Jumlah rusa kandang II } \\
\text { (Ekor) }\end{array}$ \\
\hline Jantan & 6 & 5 \\
Betina & 7 & 3 \\
Anak & 8 & 1 \\
\hline
\end{tabular}

Sumber : Hasil pengamatan di penangkaran rusa totol fakultas peternakan (2019).

Di penangkaran rusa di fakultas peternakan terdapat 3 jenis pohon yang tumbuh yaitu pohon mangga, pohon nangka dan pohon tranda besi. Pohon yang ada di penangkaran dimanfaatkan rusa tempat istirahat, bernaung dan tidur. Hal ini sependapat dengan pendapat semiadi dan taufik (2004) yang menyatakan bahwa naungan sangat diperlukan bagi rusa untuk yang berada di penangkaran. Di alam bebas, naungan akan dicari sendiri oleh rusa manakala diperlukan. Namun didalam penangkaran harus disediakan naungan untuk menghindari stres akibat dari ketidak nyamanan cuaca yang ekstrim (panas dan hujan) salah satunya dengan penanaman pohon pada area penangkaran. Selain naungan berupa pohon, pagar juga merupakan salah satu fasilitas yang harus tersedia pada penangkaran.

Sistem penangkaran rusa totol di fakultas peternakan berbeda dengan habitat aslinya di alam liar. Sistem penangkaran rusa di fakultas peternakan yaitu sistem semi-intensif. Hal pemberian pakan diatur pengelolah dan pemberian pakan 2 kali sehari yaitu pagi hari dan sore, sedangkan aktivitas lainnya dibiarkan secara alaminya. Menurut Setio (2008), pola pemeliharaan pada sistem penangkaran menyebabkan perbedaan tingkah laku pada rusa. Tingkah laku pada rusa dengan sistem pemeliharaan secara ekstensif masih menunjukkan sifat liar dibandingkan dengan sistem intensif. Pada sistem intensif, cenderung lebih jinak jika dibandingkan dengan sistem ekstensif dan semi-intensif. Oleh karenanya, domestika baik dilakukan pada penangkaran dengan sistem semi-intensif dan intensif. Namun dalam pembuatan habitat dengan sistem semi-intensif dan intensif tetap harus memenuhi kebutuhan hidup rusa seperti dihabitat alaminya, seperti sumber air dan tempat berlindung.

Tingkah Laku Rusa Akibat Pemberian Pakan Oleh Pengunjung 
Aktivitas harian rusa di penangkaran termasuk rendah, dibanding dengan aktivitas di alam. Wirdateti et al. (1997) diacu oleh Dewi at all (2015) bahwa pada rusa merah kegiatan hariannya sebagian besar 56\% digunakan untuk merumput, $22 \%$ memamah biak, $12 \%$ tidur, $5 \%$ berdiri, dan $3 \%$ berjalan-jalan. Hal ini dimungkinkan karena pakan rusa di penangkaran telah disediakan, sementara di alam rusa mencari pakan sepuasnya karena ketersediannya cukup banyak. Menurut Dewi et al. (201`5) kegiatan rusa sehari-hari di alam dan di penangkaran mempunyai proporsi yang berbeda-beda hal ini dipengaruhi oleh kondisi lingkungan dan jenis rusa.

Hasil pengamatan pada tingkah laku rusa di penangkaran yaitu tingkah laku makan, tingkah laku ruminasi, tingkah laku istirahat dan tingkah laku bermain, dapat dilihat pada Tabel 2.

Tabel 2. Tingkah Laku Rusa di Penangkaran

\begin{tabular}{|l|c|c|c|}
\hline \multicolumn{1}{|c|}{ Parameter } & P1 & P2 & P3 \\
\hline Tingkah laku makan (menit) & $141,75^{\mathrm{a} b} \pm 13,67$ & $95,75^{\mathrm{a}} \pm 25,47$ & $157,00^{\mathrm{b}} \pm 43,73$ \\
\hline Tingkah laku ruminasi (menit) & $104,00^{\mathrm{a}} \pm 27,82$ & $74,00^{\mathrm{a}} \pm 15,64$ & $147,50^{\mathrm{b}} \pm 23,74$ \\
\hline Tingkah laku istirahat (menit) & $75,00^{\mathrm{a}} \pm 23,07$ & $98,25^{\mathrm{b}} \pm 24,00$ & $63,00^{\mathrm{a}} \pm 11,10$ \\
\hline Tingkah laku bermain (menit) & $63,00^{\mathrm{b}} \pm 23,45$ & $32,00^{\mathrm{a}} \pm 7,57$ & $44,50^{\mathrm{a}} \pm 19,33$ \\
\hline
\end{tabular}

Hasil pengamatan rata-rata tingkah laku makan rusa, yaitu 13,67 \% (Tabel 2), dengan lama waktu makan 141,75 menit/12 jam. Lama waktu makan menurut Ismail (2001),

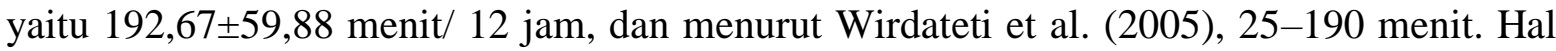
ini menunjukan bahwa lamanya waktu yang dibutuhkan rusa untuk memakan rumput tidak jauh berbeda meskipun berada di tempat yang berbeda. Perbedaan lama makan rusa disebabkan adanya perbedaan bobot badan dan jenis pakan yang diberikan (Afzalani et al., 2008). Tingkah laku makan tertinggi ditunjukkan pada saat pakan tersedia, yaitu ketika pagi pukul 08.00 - 10.00 dan sore hari pukul 16.00-18.00. Lelono (2004) menyatakan pola perilaku makan harian rusa timor terdiri atas empat periode puncak, yaitu dini $(01.00$ 03.00), pagi (06.00-08.00), siang (11.00-14.00), dan malam (17.00-20.00). Alokasi waktu untuk merumput selama periode waktu 24 jam menurut Arnold (1981) dipengaruhi oleh kebutuhan pakan, jumlah, dan distribusi vegetasi pakan, serta kecepatan makan hewan.

Tingkah laku makan rusa berbeda ketika ada pengunjung, semakin banyak pengunjung, semakin tinggi tingkah laku makan rusa. Hal ini terlihat ketika pengunjung yang datang hanya sedikit tingkah laku makan rusa rendah, sedangkan ketika pengunjung banyak yang datang tingkah laku makan rusa tinggi menjadi . Jumlah pengunjung saat kunjungan tinggi, yaitu hari minggu pagi dan sore mencapai 50 orang sehari. Pengunjung yang datang umumnya adalah anak-anak . Anak-anak senang dengan hal-hal baru yang tidak biasa dilakukan seperti memberi makan. Adanya pengunjung dapat mempengaruhi tingkat perilaku makan rusa. Rusa selalu mendekati pengunjung yang menghampiri sisi kandang walaupun tidak beri pakan.

Hasil pengamatan rata-rata waktu istirahat yaitu $23,07 \%$, dengan lama waktu istirahat 75,00 menit/12 jam.. Waktu istirahat rusa tertinggi terjadi pada siang hari, yaitu sekitar pukul 12.00-14.00 WITA, hal ini sesuai dengan pernyataan Wirdateti et al. (1997), rataan kegiatan istirahat lebih tinggi di siang hari, yaitu setelah makan sekitar pukul 13.00 16.30 WIB. Menurut Lelono (2004), aktivitas istirahat dilakukan pada pagi dan sore hari setelah aktivitas makan. istirahat rusa berbeda ketika adanya pengunjung, yaitu semakin banyak pengunjung, semakin berkurang istirahat rusa Hal ini karena adanya gangguan pengunjung, ketika ada pengunjung, rusa berdiri dan bergerak mendekati pengunjung di pinggir kandang, setelah pengunjung pergi rusa kembali berbaring untuk istirahat. Pengunjung dapat mempengaruhi waktu istirahat rusa dipenangkaran, kondisi tersebut akan berpengaruh terhadap kesehatan rusa, karena terganggunya aktivitas istirahat. 
Hasil penelitian yang telah dilakukan menunjukkan bahwa lama waktu ruminasi rusa totol terjadipada komsumsi pakan rumput gajah dengan waktu 147,5 menit. Sedangkan tingkah laku ruminasi antara pakan wortel tidak berbeda nyata meskipun lama waktu ruminasi pakan wortel lebih lama dibandingkan dengan lama waktu ruminasi pada pakan konsentrat. Hal ini disebakankarena rumput gakah memiliki kandungan serqt tinggi dan tekstur yang kasar sehingga memerlukan waktu yang cukup lama untuk dicerna berbeda dengan wortel dan konsentrat yang kadar seratnya relatif lebih rendah. Hal ini berbeda dengan hasil penelitian yang dilakukan oleh Dewi dan Wulandari (2011) melaporkan bahwa aktivitas ruminasi berkisar antara 254,92-281,28 menit per 12 jam. Perbedaan hasil penelitian yang cukup signifikan dari hasil penelitian sebelumnya disebabkan oleh perbedaan jenis rusa yang digunakan dan jenis pakan yang diberikan..

Selain aktivitas makan, ruminasi dan istirahat, rusa juga melakukan aktivitas lain disela waktu makan yaitu aktivitas bermain seperti anakan berlari dengan anakan lainnya atau berlari berkejaran dengan rusa betina dewasa lainnya. Hal tersebut ditunjukkan dengan jumlah waktu bermain yang cukup tinggi yaitu 63 menit pada pemberian pakan wortel.Tingkah laku bermain pada pemberian pakan rumput gajah tidak berbeda nyata dengan tingkah laku bermain pada pemberian konsentrat.Begitupun tingkah bermain pada pemberian pakan rumput gajah dengan wortel. Menurut wirdateti,dkk (1997) ketika makan rusa biasanya akan diselingi dengan bermain antara rusa, dalam keadaan lapar menjelang makan, rusa jarang diam, selalu berjalan-jalan disekitar lokasi penangkaran

Konsumsi Rusa Akibat Pemberian Pakan Oleh Pengunjung

Dipenangkaran rusa Fakultas Peternakan unhas pakan yang dikonsumsi rusa selain yang diberikan oleh pengelolah maupun pengunjung yang datang di penangkaran. Pemberian pakan oleh pengelolah sebanyak dua kali perhari, yaitu pukul 08.00 WIT dan sore pukul 14.00 WIT. Jenis pakan yang diberikan oleh pengelola yaitu wortel dan konsentrat, sedangkan Pakan yang diberikan pengunjung di penangkaran, yaitu wortel, kangkung, sawi, rumput liar yang ada di sekitar penangkaran.Rusa sangat menyukai pakan yang diberikan oleh pengunjung, semua jenis-jenis pakan tersebut dimakan rusa. Kandungan gizi pakan rusa disajikan pada Tabel 3 .

Tabel 3. Kandungan gizi pakan rusa di penangkaran rusa fakultas peternakan

\begin{tabular}{ccccc}
\hline Bahan pakan & BK & PK & SK & LK \\
\hline Rumput setaria $^{2}$ & 21 & 12,7 & 35 & 0,99 \\
Rumput lapang $^{1}$ & 24,40 & 2,80 & 25,70 & 0,30 \\
Wortel $^{1}$ & 91,67 & 13,16 & 6,15 & 2,05 \\
Kangkung $^{1}$ & - & 28,5 & 10,0 & 54 \\
Konsentrat $^{1}$ & 100,00 & 19,16 & 19,79 & 5,85 \\
Sawi $^{2}$ & 8,32 & 2,46 & 1,10 & 0,12
\end{tabular}

Sumber:

Dilla (2019)

Dewi at all (2015)

Hasnawati et al. (2006) menyatakan bahwa pakan rusa selain rerumputan dan dedaunan, sebagai tambahannya dapat berupa konsentrat, sayurmayur, umbi-umbian atau limbah pertanian. Tingkat kesukaan rusa terhadap pakan yang diberikan oleh pengunjung di penangkaran Fakultas Peternakan adalah disukai rusa. Hal ini dikarenakan pakan utama rusa adalah hijauan dan sayuran, di seperti wortel dan kangkung. Selain wortel dan kangkung, 
rusa juga menyukai daun mangga yang jatuh di dalam kandang. Konsumsi rusa di Penangkaran Fakultas Peternakan pemberian pakan yang berbeda menunjukan tingkat konsumsi yang berbeda pula. Hal ini akibat adanya pemberian pakan tambahan dari pengunjung. Pemberian pakan oleh pengunjung tidak memberikan pengaruh yang terhadap pola konsumsi rusa di penangkaran

Hasil pengamatan dilapangan pengaruh pola makan rusa dipenangkaran rusa di Fakultas Peternakan terhadap banyak tidaknya pengunjung yang datang dapat di lihat pada Tabel 4.

Tabel 4 Rata-rata Konsumsi Rusa Per Ekor Per Hari Pada Kondisi Tanpa Pengunjung

\begin{tabular}{lccc}
\hline & \multicolumn{3}{c}{ Jumlah Pengunjung } \\
\cline { 2 - 4 } Konsumsi Oleh & Tanpa Pengunjung & Sedikit (3-10) & Banyak (5-50) \\
\hline Pengelola (Kg) & 9,52 & 2,300 & 3,300 \\
Pengunjung & 0,00 & 0,022 & 0,330 \\
$(\mathrm{Kg})$ & & & 3,630 \\
\hline Total $(\mathrm{Kg})$ & 9,52 & 2,322 & \\
\hline
\end{tabular}

Perilaku sosial meningkat berhubungan dengan meningkatnya aktivitas makan yang diakibatkan adanya pemberian pakan oleh pengunjung dan menyebabkan terjadinya interaksi rusa dalam memperebutkan makanan. Tingkat konsumsi pakan pada rusa tanpa pengunjung sebanyak $9,52 \mathrm{~kg}$, tingkat pengunjung sedikit sebanyak $2,300 \mathrm{~kg}$ dan pengunjung banyak $3,300 \mathrm{~kg}$ secara nominal ada perbedaan. Pada rusan dipenangkaran ka pakan yang diberikan bervariasi, yaitu secara kualitas sudah mencukupi kebutuhan rusa. Hal ini disebabkan pakan yang diberikan pengelola pada rusa berupa rumput gajah ditambah wortel dan kangkung yang diberikan oleh pengunjung mempunyai kandungan nutrisi relatif tinggi dibanding dengan rumput.

\section{KESIMPULAN}

Pemberian pakan oleh pengunjung tidak memberikan perubahan tingkah laku dan pola konsumsi harian rusa, tetapi pemberian pakan oleh pengunjung menimbulkan persaingan antar rusa, sehingga perlu pengelompokan di setiap kandang berdasarkan kelas umur rusa.

\section{DAFTAR PUSTAKA}

Adiati, U. Soepono, E., Handiwirawan, A. Gunawan Dan D. Anggraeni. 1995. Pengaruh Pemberian Pupuk Kandang Terhadap Produksi Rumput Gajah( Pennisetum Purpureum) Di Kecamatan Puspo Kabupaten Pasuruan. Prosiding Seminar Nasional Peternakan Dan Veteriner, 7-8 November Di Bogor, Jilid 2:583-586.

Alikodra, H.S. 1990. Pengelolaan Satwa Liar Jilid 1. Departemen Kebudayaan. Direktorat Jenderal Pendidikan Tinggi Pusat Antar Universitas Ilmu Hayat. Institut Pertanian Bogor.

Almatzier, S. 2001. Prinsip Dasar Ilmu Gizi. PT.Gramedia Pustaka Utama.Jakarta. 
Amiati D.A.,B. Masyud dan R. Garsetiasih. 2015. Pengaruh pengunjung terhadap perilaku dan komsumsi rusa timor ( rusa timorensis de blainville 1822 ) di penangkaran hutan penelitian dramaga. Bul. Plasma nutfah 21 (2):47-60.

AOAC. 1980. Official methods of analysis of the association of official analytical chemists. Edisi ke tiga.PO BOX 540.Benjamin Franklin Station Washington DC 2004.

Bismark RM, Mukhtar AS, Takandjandji M, Garsetiasih R, Setio P, Sawitri R, Subiandono E, Iskandar S, Kayat. 2011. Sintesis Hasil Litbang:Pengembangan Penangkaran Rusa Timor. Jakarta (ID): Badan Penelitian dan Pengembangan Kehutanan.

Bunga R, M.M.H Kawatu, R.S.H Wungow dan J.J.I Rompas. 2018. Aktivitas harian rusa timor ( cervus timorensis ) di tanam marga satwa tandurusa aertembaga, bitungsulawesi utara. Zootec.38(2) : 345 - 356 .

Departemen Kesehatan (Depkes). 1981. Daftar Komposisi Bahan Makanan. Penerbit Bharata. Jakarta.

Dewi BS, Wulandari E. 2011. Studi Perilaku Harian Rusa Sambar (Cervus Unicolor) Di Taman Wisata Alam Bumi Kedaton.J.Sains MIPA. 17(2):75-82.

Direktorat Gizi Departemen Kesehatan RI. 1996. Daftar Komposisi Zat Gizi Pangan Indonesia.Departemen kesehatan RI. Jakarta.

Dradjat, A. S. 2000. Penerapan Teknologi Inseminasi Buatan, Embrio Transfer dan In Vitro Fertilisasi pada Rusa di Indonesia: Suatu Cara UntukMencegah Hewan Langka dari Kepunahan. Laporan Riset UnggulanTerpadu V Bidang Teknologi Perlindungan Lingkungan.KantorMenteri Negara Riset dan Teknologi.Dewan Riset Nasional. Jakarta.

Fajri, 2000. Perilaku harian Rusa Totol (Axis axis) yang dikembangbiakan di padang rumput halaman Istana Negara Bogor. [Skripsi]. Bogor (ID): Jurusan Ilmu Produksi Ternak, Fakultas Peternakan, Institut Pertanian Bogor.

Garsetiasih R, dan Takandjandji M. 2006. Model Penangkaran Rusa. ProsidingEkspose Hasil-hasil Penelitian.Konservasi dan Rehabilitasi SumberdayaHutan.PSIH-IPB; Puslit Biologi; Puslitbang Hutan dan Konservasi Alam,Departemen Kehutanan. Bogor.

2007. Model Penangkaran Rusa. ProsidingEkspose Hasil-Hasil Penelitian. Padang. Hlm 12.

Garsetiasih. 1990. Potensi Lapangan Rerumputan Rusa di P. Menipo pada Musim Kemarau. Laporan Teknis. Balai Penelitian Kehutanan Kupang.

Hasnawati, H. S. Ali kodra, dan A. H. Mustari 2006. Analisi Populasi dan Habitat sebagai dasar pengelolah Rusa Totol ( axis - axis ) di jakarta, Media konservasi II (2) 46 - 57.

Intannita, T. 2003. Performans mandalung (mule duck) dengan taraf penambahan kangkung(ipomoea aquatica) yang berbeda dalam ransum. Skripsi. Fakultas peternakan institute pertanian bogor. Bogor. 
IUCN, 2015 International Union for Conservation of Nature and Natural Reserves. 2015. The Redlist of Threathened Species. http://www.iucnredlist.org. diakses 8 Oktober 2015.

Lelono, A. 2004. Ekologi Perilaku Makan Rusa (cervus timorensis Lyd) dalam Penankaran di Ranca Upas Ciwidey. Tesis S2, Institut Teknologi Bandung, Bandung.

Lugiyo dan Sumarto. 2000. Teknik BudidayaRumput Gajah cv Hawaii (Pennisetumpurpureum). Prosiding Temu TeknisFungsional Non Peneliti.Diterbitkan PusatPenelitian dan Pengembangan Pertanian.Departemen Pertanian :Hal.120 - 125.

Makmun, C. 2007. Wortel Komoditas Ekspor Yang Gampang Dibudidayakan.Hortikultura: Hal. 32.

Malasari. 2005. Sifat fisik dan organoleptic nugget ayam dengan penambahan wortel(Daucuscarota L.,). Skripsi.FakultasPeternakan.Institut Pertanian Bogor.Bogor.

Masy'ud, B., R. Wijaya, dan I.B. Santoso. 2007. Pola distribusi dan aktivitas harian rusa timor (Cervustimorensis de Blainville 1822) di Taman Nasional Bali Barat. Media Konservasi 12(3):10-15.Mendukung Pembangunan Daerah dan Kesejahteraan Masyarakat Provinsi Kalimantan Barat. Pontianak: hal.11-13 Desember 2007.

Mas'ud AF, Dewodaru, Komar TE, Muktar AS, Bismark M, Sawitri R, Iskandar S, Kosasi AS, Pratiwi And Anwar C. 2011. Status dan sintesa hasil litbang : konservasi keanekaragaman satwaliar. Bogor: Badan Penelitian dan Pengembangan Kehutanan.

Mihran, 2008.Evaluasi penyuluhan penggunaan bokashi kotoran sapi terhadap pertumbuhan dan produksi rumput gajah, Jurnal Agrisistem, juni 2008 Vol.4 no.1.

Muchtadi, D. 1998. Kajian Terhadap Serat Makanan Dan Antioksidan Dalam Berbagai Jenis Sayuran Untuk Pencegahan Penyakit Degenerative.Press. Bogor.

Mukhtar, A.S. 1996. Studi Dinamika Populasi Rusa (Cervus TIMORENSIS) DALAMMenunjang Manajemen Taman Buru Pulau Moyo. Disertasi S3 Institut PertanianBogor, Bogor.

Pattiselanno F, Isir DA, Takege A, Seseray D. 2008. Kajian awal penangkaran Rusa (Cervus timorensis) sistem back yard di Manokwari, Papua Barat. Biodfer. 25(2): 95-100.

Polii, G.M.M. 2009. Respon Produksi Tanaman Kangkung Darat ( Ipomean Reptans Poir) Terhadap Variasi Waktu Pemberian Pupuk Kotoran Ayam. Journal Soil Environment Vol. VII No.1.5hlm.

Rihatni, R. 2013. Resfrensi Pakan Tambahan Limbah Sayuran pada Rusa Timor (Rusa Timorensis) di penangkaran dan pengaruhnya Terhadap Periku Makan. Skripsi. Intitut Pertanian Bogor. Bogor.

Rosviani, L. 2018. Manajemen Penangkaran Rusa Timor ( rusa timorensis ) di taman Rusa Bumi Patra, Indramayu, Jawa Barat. Skripsi. Fakultas Kehutanan. Institut Pertanian Bogor. 
Rubatzky, V.E. dan M. Yamaguchi. 1997. Sayuran Dunia 2. Agromedia pustaka, Jakarta.

Rukmana, R. 1995. Bertanam Wortel, kanisius, Yogyakarta. Hal 13-18.

2005. Rumput Unggul Hijauan Makanan Ternak. Kanisius. Yogyakarta.

Rusilanti dan C. M. Kusharto. 2007. SehatDengan Makanan Berserat. AgromediaPustaka.Jakarta Selatan.

Santoso, S I. 2011.Rusa Timorensis (Cervus timorensis). Graha Ilmu.Indonesia: Hal.1-3.

Sari, N. K. 2009.Produksi bioethanol darirumput gajah secara kimia. Jurnal TeknikKimia, 4 (1): $265-273$.

Semiadi, G. dan R. T. Nugraha. 2004. Panduan Pemeliharaan Rusa Tropis. Pusat Penelitian Biologi. Lembaga Ilmu Pengetahuan Indonesia. Bogor.

Semiadi , G., Barry, dan T.N. Muir, P.D 1998. Perubahan berat badan rusa sambar (cervus unicolor) pada kondisi padang rumput di daerah beriklim sedang. Bogor. Biologo Indonesia. 2: $104-108$.

Setio P. 2008. Penangkaran Rusa. Prosiding Ekspose dan Gelar Teknologi Hasilhasil Penelitian.

Setio P, Iskandar S, Sudaryo C. 2011. Teknik peningkatan reproduksi penangkaran rusa. Laporan Hasil Penelitian. Pusat Litbang Konservasi dan Rehabilitasi Kehutanan, Bogor (ID).

Sita, V., dan aunurohim. 2013. Tingkah laku makan rusa sambar rusa unicolor dalam konservasi ex-situ di kebun binatang surabaya. Institut Teknologi Sepuluh November. Surabaya. 2(1):174.

Suratman, Dwi Priyanto, Ahmad Dwi Setyawan. 2000. Analisis Keragaman Genus (Ipomoea Berdasarkan Karakter Morfologi. Jurusan Biologi Fmipa Uns Surakarta Voume 1, Nomor 2 Halaman: $72-79$.

Takandjandji, M. 2009. Desain Penangkaran Rusa Timor Berdasarkan Analisis Komponen Bioekologi Dan Fisik Di Hutan Penelitian Dramaga.Tesis S2, Institut Pertanian Bogor, Bogor.

Tillman, A.D. 1991. Komposisi Bahan Makanan Ternak Untuk Indonesia.Gadjah Mada University Press.Yogyakarta.

Tillman, A. D., H. Hartadi, S. Reksohadiprojo, S. Prawirokusumo. 1999. Ilmu Makanan Ternak Dasar. Gadjah Mada university Press, Yogyakarta.

Wanamarta, G. 1981. Produksi Dan Kadar Protein Umbi 5 Varietas Ubi Jalar Pada Tingkat Pemupukan NPK. Departemen agronomi, fakultas pertanian institute Atlanta. Hlm 1112.

Wirdateti, W. R. Farida, dan M. S. A. Zein. 1997. Perilaku harian rusa jawa (cervus timorensis) di penangkaran taman safari Indonesia. Biota 2 (2):78-81. 